\title{
Aplicación de normas y principios del Código Civil en los contratos administrativos: análisis jurisprudencial
}

\author{
Application of norms and principles of the Civil Code \\ in administrative contracts: jurisprudential analysis.
}

\author{
Carolina Alejandra Pincheira Sepúlveda (iD \\ Universidad de Santiago de Chile
}

\begin{abstract}
RESUMEN Si bien la Ley 19.886 de Bases sobre Contratos Administrativos de Suministro y Prestación de Servicios establece un orden de prelación legal a aplicar en los contratos administrativos objeto de la norma, esto no necesariamente se respeta a cabalidad. A juicio de este trabajo, la causa es clara y tiene relación con la resolución de conflictos sobre contratación administrativa por los tribunales civiles. Debido a esto, la jurisdicción civil toma un rol protagónico y se hace cargo de una materia específica como la contratación administrativa, reflejando la preeminencia de las normas civiles por sobre lo establecido en la ley y en las normas de derecho público, resolviendo generalmente con énfasis en principios generales del derecho y asimilaciones a instituciones propias del derecho privado. Parece relevante señalar que si bien en este trabajo fueron revisadas las sentencias que aplican los principios de la contratación administrativa para resolver, esta no es una constante en las resoluciones judiciales, y que existen tribunales que intuitivamente resuelven aplicando únicamente el derecho civil sin considerar aspectos particulares del derecho administrativo. En consecuencia, es necesaria una revisión exhaustiva del contrato por parte de los jueces para la correcta aplicación de los diferentes ámbitos del derecho que conviven para la resolución de los casos, al menos mientras no exista jurisdicción especial.
\end{abstract}

PALABRAS CLAVE Administración pública, contratos administrativos, cláusulas exorbitantes, derecho público, derecho privado.

ABSTRACT The Law 19.886 establishes a legal order of priority to apply in the administrative contracts that are the object of the regulation, this is not necessarily respected. The above, in the opinion of this author, has a clear cause: the resolution of conflicts over administrative contracting by civil courts. Due to the foregoing, the civil jurisdiction takes a leading role, taking charge of a specific matter such as administrative contracting, reflecting the preeminence of civil norms over what is established in Law 19.886 and in the rules of Public Law, generally resolving with emphasis in general principles of law and assimilations to private law institutions. It seems relevant to point out that although sentences were 
passed that apply the principles of administrative contracting to resolve, it is not a constant in judicial decisions, there are courts that intuitively resolve applying only the civil law, without considering particular aspects of administrative law, for what is necessary a thorough review of the contract by the judges, for the correct application of the different areas of law that coexist for the resolution of cases, at least while there is no special jurisdiction.

KEYWORDS Public administration, administrative procedure, exorbitant clause, public law, private law.

\section{Aproximación doctrinal a la dicotomía público-privado en la contratación pública}

El artículo primero de la Ley 19.886 de Bases sobre Contratos Administrativos de Suministro y Prestación de Servicios, establece el fundamento para la aplicación de normas civiles a la contratación administrativa. Al respecto, señala que:

Los contratos que celebre la administración del Estado, a título oneroso, para el suministro de bienes muebles, y de los servicios que se requieran para el desarrollo de sus funciones, se ajustarán a las normas y principios del presente cuerpo legal y de su reglamentación. Supletoriamente, se les aplicarán las normas de derecho público y, en defecto de aquellas, las normas del derecho privado.

En consecuencia, establece un orden de prelación en la aplicación normativa resultando residual en último grado la aplicación de las normas y principios del Código Civil. Al respecto, es relevante precisar algunos aspectos propios de la contratación administrativa que resultan útiles al momento de efectuar un análisis relacionado con la aplicación de las normas y principios del Código Civil por la jurisprudencia judicial y administrativa, los cuales han sido sistematizados por la doctrina. Estos aspectos serán dispuestos a continuación.

En relación con la «neomoderna legislación administrativa", Alejandro Vergara Blanco (2014: 44) identifica la necesidad de clasificar la normativa pública o privada con el objeto de identificar normas que, en caso de vacíos o lagunas, es posible aplicar por vía supletoria en materia de contratación administrativa requiriendo elementos para la correcta integración normativa. Sobre la relación entre el ámbito público y privado del derecho concluye que:

No parece adecuada, ante lagunas normativas, la utilización de técnicas de integración normativa, como la supletoriedad, entre disciplinas de los sectores contrapuestos del derecho; y es problemática, pues las normas así integradas lo hacen sin los ajustes que incorpora el jurista a través del delicado proceso de construcción de principios jurídicos desde y hacia sectores bipolares contrapuestos, que no comparten bases esenciales ni principios jurídicos entre sí. 
Finalmente, con respecto a la igualdad entre las partes, Vergara Blanco (2014: 44) precisa que:

En el derecho administrativo la relación no es de igual a igual, sino que se trata de la persona frente a los organismos del Estado. Aunque las personas y los órganos del Estado sean sujetos de derecho, y puedan enfrentarse ante un tribunal, la relación o enfrentamiento en los hechos es desigual.

Por otra parte, Osvaldo Oelckers Camus (1979: 137) plantea que:

A consecuencia de la intromisión del Estado en todo el sistema contractual, la actividad administrativa pública crece y absorbe una serie de funciones que para su realización se inspira, construye y desarrolla conforme a las realidades del derecho privado, especialmente en el campo patrimonial.

Adicionalmente, con respecto al contrato administrativo, el mismo autor señala que «sus elementos esenciales y su técnica jurídica siguen al contrato civil, pero su régimen jurídico, su fondo, está constituido por particularidades del derecho administrativo» (Oelckers Camus, 1979: 137). Por otra parte, determina la existencia de criterios de diferenciación como la presencia de cláusulas exorbitantes; el objeto del contrato a través del servicio público ampliado como realización de una actividad que implica la satisfacción directa de un interés común o público concreto; la categorización de los elementos esenciales del contrato como la necesaria presencia de la administración; el servicio público como objeto del contrato y el giro propio de la administración.

En relación con las cláusulas exorbitantes, Moraga Klenner (2007: 219-220) expone que no son de por sí la gran peculiaridad de los contratos que celebra la administración, precisando que las prerrogativas de la administración se tienen y se ejercen solamente cuando la contraparte en el contrato es un privado, con base en la desigualdad de las partes. Agrega que la causa de las prerrogativas de poder público se encuentra en el hecho de que la administración no solo tiene el derecho de exigir la prestación debida por el particular contratante, en tiempo y forma, bajo apercibimiento de imponer las sanciones dispuestas por el ordenamiento jurídico o por el propio contrato, sino que también es titular de ciertas prerrogativas generales o especiales exorbitantes al derecho privado, que encuentran su justificación en el hecho de que en cada contrato de la administración existe un interés público por el que se debe velar.

Por otro lado, Ricardo Concha Machuca (2013: 470) determina que:

El contrato de la administración del Estado crea derechos y obligaciones del mismo modo que el contrato de derecho privado, y así es posible comprender desde el derecho de las obligaciones el fenómeno de la fuerza vinculante del contrato de la administración del Estado [...] Lo anterior determina que la eficacia del contrato de la administración quede compelida por la intangibilidad de la norma contractual, bajo el régimen jurídico «del efecto de las obligaciones», según el título XII del libro IV del Código Civil, es decir, el régimen de responsabilidad contractual. 
Sobre el término anticipado del contrato administrativo, Patricio Ignacio Carvajal (2016: 107-108) reseña que:

Es una facultad de carácter completamente excepcional y, por cierto, en ningún caso se considera ilimitada. Se trata, pues, de una facultad conferida a la administración en virtud de normas expresas del derecho público, si bien ciertos aspectos no tratados por estas se regulan supletoriamente por el derecho privado.

Además, manifiesta que la excepcionalidad deriva de tres factores. En primer lugar, de que las normas que facultan para la terminación anticipada deben intervenir e interpretarse excepcionalmente y por motivos fundados con base en el inciso 2 del artículo 19 número 21 de la Constitución; luego, la terminación anticipada priva al particular de sus derechos emanados, como concesionario del artículo 19 número 24 de la Constitución; y finalmente porque la administración solo puede hacer aquello a lo que autorice expresamente la ley. El mismo autor agrega que:

Del punto de vista del derecho privado, según las normas que rigen la contratación entre los particulares no le es permitido a ninguna de las partes extinguir el contrato unilateralmente, pues ello infringiría la ley del contrato (artículo 1.545 del Código Civil). Por lo tanto, resulta a todas luces evidente que las normas de derecho público que admiten esta terminación anticipada de la concesión administrativa son del todo excepcionales. Pero, además, todavía desde la perspectiva del derecho privado [...] como estas normas se aplican supletoriamente a la terminación administrativa anticipada por incumplimiento (aunque en el caso civil, jamás se admitiría esta terminación sin siquiera una declaración judicial), se puede añadir a las razones que hacen de la terminación anticipada de la concesión, en general, una institución excepcional, que si dicha terminación se funda en el incumplimiento contractual del concesionario, también tiene tal carácter según el derecho privado, ahora por razones particulares a la causa de esta terminación (Carvajal, 2016: 107-108).

En las siguientes páginas se abordará la aplicación de las normas y principios contenidos en el Código Civil aplicables a la contratación administrativa, identificando el uso recurrente de las mismas, la integración normativa y las posibilidades de establecer una propuesta de aplicación general unificadora o, al menos, complementaria de lo público y lo civil. Todo lo anterior con base en la jurisprudencia reciente de los tribunales superiores de justicia y la jurisdicción civil, además de la revisión de pronunciamientos relevantes de la Contraloría General de la República.

\section{Análisis de jurisprudencia}

\section{Jurisprudencia de los tribunales civiles}

Los tribunales civiles han sometido a su conocimiento conflictos propios de la inexistente jurisdicción contenciosa administrativa de manera recurrente. Esto con el objeto principal de entregar criterios y soluciones que equilibren la relación entre las partes, 
el análisis de la aplicación de las prerrogativas propias de la administración y la terminación anticipada del contrato como temáticas principales. En este sentido, la jurisprudencia reciente entrega luces con respecto a la convivencia entre la normativa del derecho público y el derecho civil, cuyo carácter supletorio resulta discutible cuando se trata de la aplicación en ciertos apartados del derecho común.

Sentencia del 2. ${ }^{\circ}$ Juzgado Civil de Viña del Mar, rol C-186-2014, del 8 de septiembre de 2017

Se conoce la demanda de cumplimiento de contrato con indemnización de perjuicios por concepto de daño emergente y lucro cesante interpuesta por la Inmobiliaria y Constructora San Mateo, cuyos perjuicios son representados en los costos de ejecución de obras adicionales, extraordinarias, y los gastos generales por los mayores tiempos de ejecución de obras adjudicadas previa licitación pública para la reposición del Centro de Salud Familiar Gómez Carreño y el laboratorio comunal. El contrato fue firmado el 19 de junio de 2012. La demandante argumenta que debe acudir a una sede neutral a solicitar una medida prejudicial precautoria y, posteriormente, demandar el cumplimiento del contrato con indemnización de perjuicios en razón de las facultades exorbitantes ejercidas por el servicio de salud y el inspector técnico de la obra en el contrato titulado «Aumento y modificaciones de contrato, obras extraordinarias y/u obras nuevas», las cuales a juicio de la demandante han sido ejecutadas de manera injustificada, desviada e ilegal.

Sobre el contrato administrativo, la demandante señala que presenta una serie de notas diferenciadoras con respecto a la contratación civil y destaca la desigualdad entre las partes, caracterizada por la superioridad respecto del contratista justificado por el interés público que hay detrás de la ejecución del contrato. Sin embargo, dicha superioridad no puede sustentarse cuando un funcionario público intenta protegerse de sus propios errores, los que se manifiestan en la modificación unilateral del contrato, la interpretación y la aplicación de sanciones.

Como consecuencia, el tribunal acoge la demanda de cumplimiento de contrato con indemnización de perjuicios. En el considerando vigésimo señala que los contratos administrativos corresponden a los que han sido:

Celebrados entre un órgano de la administración del Estado y un particular u otro organismo público, cuyo objeto es satisfacer de manera directa e inmediata un fin de interés público a través de la aplicación de un régimen normativo de derecho administrativo.

Por otra parte, agrega que la doctrina y jurisprudencia mayoritaria ha señalado que existe una desigualdad entre las partes toda vez que el régimen jurídico no puede significar un riesgo o peligro para el buen y adecuado funcionamiento del servicio público, configurando un proceso dinámico, adaptable a las circunstancias y situaciones producidas en el desarrollo del contrato. 
Dentro de los principios que regulan la contratación administrativa se encuentran el respeto a las bases administrativas, la sujeción a lo pactado, la buena fe y la equivalencia de las obligaciones en favor de no existir enriquecimiento sin causa. Dicho régimen se expresa en las leyes 19.880, 19.886 y en su reglamento. Así, rige en ausencia de regulación específica relativa a la contratación administrativa, aplicación supletoria del derecho público y, en su defecto, del derecho privado, por lo que en el caso concreto es posible invocar dichas normas para impugnar el contrato administrativo de ejecución de obras con aplicación del artículo 1489 del Código Civil, que consagra la condición resolutoria tácita.

Sentencia del $17 .^{\circ}$ Juzgado Civil de Santiago, rol C-8783-2016, del 16 de agosto de 2017

Este caso de relevancia supone la demanda de cumplimiento de contrato e indemnización de perjuicios en juicio de hacienda interpuesta por el fisco contra la Importadora y Comercializadora Work Ltda. Se basa en el incumplimiento de la entrega de 243 pares de zapatillas destinadas a los aspirantes de oficiales del primer escuadrón de la Escuela de Carabineros del año 2014 por un precio total de $\$ 8.646 .183$, circunstancia que supone el pago de una multa ascendiente a \$9.205.392 más reajustes e intereses corrientes calculados desde la fecha de su constitución en mora más costas del juicio. Como antecedentes relevantes se señala que la oferta fue publicada en el portal Mercado Público y que fue aceptada por Carabineros de Chile por resolución exenta número 205 con fecha 7 de abril de 2014. La suscripción de contrato ocurrió el 6 de mayo de 2014 y la orden de compra se emitió el 14 de mayo del mismo año. Posteriormente, el 26 de mayo de 2014 se incumplió el plazo de diez días para la entrega, fecha acordada en la cláusula quinta del contrato, por lo que la institución decidió terminar anticipadamente el contrato.

El fundamento jurídico de la demanda recae en los artículos 1437, 1438, 1489, 1535, 1545 y 1551 del Código Civil, referidos al cumplimiento de los contratos, la condición resolutoria tácita, la cláusula penal y la constitución en mora.

La empresa contesta la demanda y señala que la institución realizó requerimientos que no se encontraban en las bases de la licitación, motivo por el cual ofrecieron completar la cantidad solicitada con modelos similares, sin embargo, se dio término anticipado al contrato sin previo aviso.

El tribunal acoge la demanda y condena a la parte demandada al pago de \$9.205.392 a título de cláusula penal, revisando en sus considerandos sexto a noveno la aplicación de la normativa civil en los contratos administrativos y señalando que tanto la regulación como sus efectos jurídicos no solo se rigen por el derecho público, sino también por el derecho privado supletoriamente. Además, en el considerando séptimo establece que:

La figura del contrato, como acuerdo de voluntades que genera derechos y obligaciones entre quienes lo celebran, constituye una institución que trasciende la división del derecho en público y privado. 
Por otra parte, el tribunal agrega que el contrato administrativo presenta diferencias esenciales con respecto al contrato de derecho privado, basado en la distinta naturaleza de los sujetos involucrados, y establece que el Estado, al momento de contratar, lo hace para satisfacer una necesidad o interés público, consagrándose prerrogativas y potestades exorbitantes para la administración como la facultad de poner término anticipado del contrato por incumplimiento de las obligaciones del contratante. Finalmente, como afirma el contralor Jorge Bermúdez Soto en su Monografía sobre Derecho Administrativo General, que se cita en la sentencia analizada:

La contratación administrativa se rige por el principio de legalidad y ley del contrato, el cual supone, por una parte, que la administración debe actuar (contratar) previa habilitación y sin contradicción con el ordenamiento jurídico; y por otra, que las partes no solo están obligadas por el tenor del contrato, sino también por la normativa que lo regula, la cual se entiende incorporada al contrato. Asimismo, dicho autor expresa que resulta particularmente relevante el principio de ejecución de buena fe del contrato, el cual se traduce en que surge para ambos contratantes la obligación de lograr la realización de la finalidad del contrato, es decir, satisfacer el interés general, aportando cada uno de ellos los máximos esfuerzos y diligencias en su ejecución. (Sentencia del $17^{\circ}$ Juzgado Civil de Santiago rol C-8783-2016, 2017: considerando octavo)

Sentencia del 3. Juzgado Civil de Concepción, rol C-1140-2015, del 8 de junio de 2016

Este procedimiento se inicia cuando la empresa Vital Ltda. demanda en juicio ordinario por una resolución de contrato con indemnización de perjuicios al SERVIU de la región del Biobío. El demandante solicita que la boleta bancaria de garantía número 6407789 del Banco Estado, que cauciona el buen comportamiento y la buena ejecución de las obras referidas al contrato administrativo previa licitación pública denominado «Construcción conjuntos habitacionales Camilo Olavarría 100 familias» fue ordenada cobrar y ejecutar por la institución fuera de los casos que el contrato y las normas que lo regulan le permitían, solicitando el demandante que se condene al demandado al pago del importe de la boleta por un total de 4.407 UF más intereses legales con costas.

En este escenario, el tribunal aceptó la demanda y en su considerando duodécimo señaló que:

El contrato administrativo es una ley para los contratantes, no siendo jurídicamente posible dejarlo sin efecto o no cumplirlo por un motivo no contemplado en este. En efecto, todo contrato administrativo se rige por sus cláusulas, por las normas legales y reglamentarias que lo regulan, por las bases de licitación, por la oferta adjudicada y por las demás prescripciones técnicas, por lo que no es posible decidir en contra de la ley del contrato, pues se transgrede el principio de la autonomía de la voluntad.

De este modo, el tribunal establece que la controversia a resolver consiste en determinar los términos de un contrato y las infracciones a los deberes que impone, por lo 
que al tratarse de una problemática de interpretación y ejecución del contrato supone la posibilidad de aplicar el procedimiento ordinario que origina la acción interpuesta en estos autos.

Por otra parte, se agrega que por tratarse de un contrato de naturaleza administrativa una de sus principales características radica en que la administración se encuentra revestida de facultades exorbitantes en relación con el contratista, fundado en la finalidad de interés público que dicho contrato busca satisfacer, sin embargo, aun aplicando la presunción de legalidad de los actos de la administración, el mérito del proceso da cuenta de que el demandante ha cumplido las obligaciones contraídas, aplicando principalmente para su resolución los artículos 1437, 1438, 1445, 1487, 1489, 1545, 1546, 1547, 1551, 1560 y siguientes del Código Civil.

Sentencia del 3. ${ }^{\circ}$ Juzgado de Letras de Punta Arenas, rol C-484-2017, del 2 de mayo de 2017

En esta causa el Fisco de Chile demanda a la empresa IVENS S.A. por incumplimiento de contrato e indemnización de perjuicios en juicio ordinario de hacienda en razón de no proveer una planta generadora de nitrógeno líquido en territorio antártico chileno. En su reemplazo, la empresa hizo entrega de una planta deficiente. Como consecuencia, el demandante tuvo que solventar gastos y costos a consecuencia del incumplimiento que ascendieron a la suma de \$12.974.466.

El tribunal acogió la demanda de cumplimiento forzado e indemnización de perjuicios en rebeldía del demandado, ya que por ser el contrato de autos un contrato administrativo de suministro fue posible aplicar las normas del derecho privado en defecto de las normas del derecho público, las cuales aplican supletoriamente a la Ley 19.886 y su reglamento. En particular, se aplicaron los artículos 1489 y 1546 del Código Civil. Con respecto al cumplimiento forzado del contrato se señaló que, en virtud de las bases administrativas, se debía garantizar la buena calidad de los productos a entregar, siendo responsables en caso de reclamos fundados y estableciendo como garantía de fiel cumplimiento la entrega de una boleta de garantía bancaria, la cual no fue cobrada por haber perdido su vigencia con anterioridad a la recepción del equipo. Igualmente, procede indemnización de perjuicios por existir un incumplimiento grave de las obligaciones del contrato por parte del demandado, siendo imputable al demandado probando la existencia de la obligación mediante el contrato de compraventa de la planta generadora de nitrógeno líquido no objetado.

Sentencia del $3 .^{\circ}$ Juzgado de Letras de Calama, rol C-115-2016, del 7 de abril de 2017

En autos se observa que la empresa de marketing VITRAUX demanda por cobro de prestaciones en juicio sumario a INDAP en razón de la prestación de servicios adicionales al contrato denominado «Organización, producción y montaje de la Feria Expo 
Rural Antofagasta, 2011», suscrito con fecha 30 de diciembre de ese año bajo el alero de la resolución exenta 60-467 de la misma fecha. Los servicios consistieron, entre otros, en el cambio de la parrilla de artistas y la preparación del pastel de choclo más grande del mundo sin suscribir una modificación de contrato previo, reconociendo con posterioridad y mediante addendum como partidas adicionales la suma de \$20.141.741, documento que no fue firmado por la empresa al ofrecerse una suma menor a la indicada y no considerar la cantidad de $\$ 1.000 .000,{ }^{1}$ razón por la cual la deuda demandada asciende a \$21.141.741 más reajustes e intereses. Estos fundamentos jurídicos suponen la aplicación del artículo 12 de las bases, que indican la posibilidad de modificar el contrato de común acuerdo, el artículo 1545 del Código Civil y el principio de enriquecimiento sin causa.

INDAP contesta la demanda y señala que no hay acto jurídico que la obligue a pagar una suma distinta a la señalada en el contrato, la cual se encuentra íntegramente pagada, indicando que no se dictaron resoluciones administrativas que fundamenten la pretensión.

El tribunal se remite a los dictámenes de la Contraloría General de la República número 88.496 de 2015, 44.066 de 2009, y 27864 de 2014 para acoger la demanda. En el considerando décimo sexto se señala que:

La jurisprudencia administrativa ha concluido que los servicios públicos no pueden aprovecharse de sus propios errores en perjuicio de terceros y que, por otro lado, como lo previene el dictamen número 15.915 de 2005, se produciría con ello un enriquecimiento sin causa para la entidad pública.

En el mismo considerando, el tribunal cita la sentencia de la Corte Suprema en causa rol 10666-2015, que establece que:

Además, pesa sobre todo contratante el deber de actuar de buena fe, que le impone el artículo 1546 del Código Civil, el que debe extender incluso a aquellos que las partes

\footnotetext{
1. A modo de aclaración se debe señalar que de acuerdo con las bases de la licitación, la oferta presentada por Vitraux y del contrato que las bases suscribieron todo indica que INDAP dispuso un presupuesto de \$60.000.00o para montaje, producción y organización de la Expo Rural 2011, que Vitraux presentó una oferta por $\$ 67.834 .213$ y propuso que INDAP pagara $\$ 59.897 .713$, y que Vitraux en autogestión generaría \$17.500.000 que INDAP aceptó y consignaron las partes en el considerando cuarto del contrato donde expusieron que "por la totalidad de los servicios INDAP se compromete a pagar \$59.897.713». Sin embargo, al proponer un adendum a este contrato, INDAP modificó el monto del presupuesto de $\$ 59.897 .713$ a $\$ 68.500 .000$. La oferta económica adjudicada de $\$ 67.834 .213$ a $\$ 77.397 .713$, de los cuales se financiaría $\$ 59.897 .713$ y $\$ 17.500 .000$ serían autogestionados, reconociendo que efectivamente se ejecutaron \$58.551.107; las partidas adicionales ascendían a \$20.141.741, adicionales por publicidad \$14.738.708 y otros producción $\$ 5.403 .033$, y que el costo total del contrato era de $\$ 78.692 .848$, impuestos incluidos, de los cuales se compromete al pago de $\$ 68.500 .000$ a Vitraux quedando el saldo con cargo al dinero auto gestionado y ofertado por la actora. En consecuencia, a la utilidad que consistía en la autogestión de \$17.500.0oo, según la oferta que INDAP aceptó, el demandado pretendió imputar parte del costo del contrato, motivo por el cual la actora se negó a suscribir la modificación del contrato.
} 
pudieran convenir consensualmente, en consecuencia este argumento del demandado será desestimado. A mayor abundamiento, los órganos del Estado deben someter sus actuaciones a la Constitución y a las leyes, debiendo actuar dentro de su competencia y en la forma prescrita por la ley y «no están liberados de sujetarse a los principios y normas que rigen en materia civil».

Se tiene presente que las bases de licitación fueron redactadas unilateralmente por INDAP, sin intervención de terceros, y en ellas se contempló que el contrato podía modificarse de común acuerdo siendo sancionado por un acto administrativo. Agrega que la naturaleza de acto administrativo que adjudica un servicio en favor de un particular es compleja, ya que obliga al acto órgano del Estado a suscribir un contrato con un civil, constituyendo la unión entre un acto administrativo unilateral de la administración que a la vez genera obligaciones recíprocas entre los contratantes.

El acto previo al contrato es, por tanto, una facultad discrecional de la administración a través de un acto de autoridad y, en ejercicio de su potestad administrativa, decide transferir a particulares la satisfacción de una necesidad colectiva. El contrato tiene una naturaleza contractual solo en cuanto crea derechos, ya que constituye una declaración bilateral productora de efectos jurídicos entre dos personas, una de las cuales es un órgano de la administración del Estado que actúa en ejercicio de la función administrativa. Por lo anterior, es posible observar que pese a su naturaleza contractual pueden aplicarse normas del derecho público. En el considerando vigésimo se cita al profesor Eduardo Soto Kloss, quien indica que:

Dada la naturaleza del fin que persigue la administración (fin público/bien común), y dada su propia posición jurídica dentro del ordenamiento jurídico estatal (posición supraordenadora, atendida esa finalidad), el régimen jurídico de la contratación administrativa es un régimen de derecho público, pues que mira a la utilidad común, baste para ello observar el contenido del artículo 7 de la Ley 19.886.

En este sentido, los actos administrativos y antecedentes de la licitación son instrumentos de derecho público, y es la voluntad imperante la que tiene por finalidad el bien común dejando de ser un acto eminentemente privado.

Se señala que siendo las normas del derecho público insuficientes para dar vida a un contrato por el imperativo de poder únicamente aquello que autoriza expresamente la ley, es que preferentemente es necesario recurrir al derecho civil para interpretar o definir palabras como «mora», «incumplimiento», «terminación», "pago», «indemnización», y en general las que conllevan la vida de un contrato, resultando del todo aplicable el 1545 del Código Civil. Según el considerando vigésimo, el derecho público no es autosuficiente a diferencia del derecho civil, cuya aptitud es «aplicar válidamente sus categorías y principios generales para deducir reglas no escritas aplicables a los hechos que no se encuentran regulados ni por el Código Civil ni por una ley sectorial».

El tribunal aplica el Código Civil para resolver, en específico el artículo 2515 en relación con los plazos de prescripción y el artículo 1546 en relación con la buena fe, en 
cuanto INDAP no puede beneficiarse de sus propios errores al no sancionar mediante el acto administrativo las modificaciones del contrato que significaron los servicios que obtuvo la actora, por lo que acoge la demanda interpuesta y ordena al demandado a pagar la suma de \$19.549.371 más reajustes e intereses corrientes.

\section{Sentencia del $4 .^{\circ}$ Juzgado Civil de Valparaíso, rol C-1001-2014,} del 24 de marzo de 2017

En este caso, Luis Alberto Bianco Ingeniería y Construcción IRL demanda en juicio ordinario a la Municipalidad de Valparaíso por el cumplimiento de contrato y la indemnización de perjuicios en base a no haberse respetado lo que originalmente se pactó, específicamente en lo que respecta a la construcción de una plaza con un área de juegos y máquinas de ejercicios debido a que el lugar físico determinado originalmente no corresponde al mostrado en la visita obligatoria ni a lo detallado en los planos relativos a la construcción del proyecto.

El fundamento jurídico de la demanda contempla la aplicación de los artículos 1545, 1546, 1556 y siguientes del Código Civil, en cuanto estima necesario valorar la conducta de la demandada con carácter de organismo gubernamental, cuya actuación se espera que esté adecuada a los más altos estándares de ejecutabilidad en materia contractual.

El tribunal señala que sin perjuicio de la calidad de contrato administrativo del acuerdo, no existe inconveniente para la revisión del incumplimiento contractual en sede civil aunque ya se hubiera resuelto en sede administrativa, señalando que tanto la doctrina como la jurisprudencia se encuentran contestes en que una resolución administrativa no es obstáculo para que la parte afectada entable acciones para revisar la legalidad de los actos de la administración y demande indemnización de perjuicios, siguiendo la tesis de la Corte Suprema en la Sentencia rol 24.237-2014, de 2014.

Sentencia del $1 .^{\circ}$ Juzgado Civil de Valdivia, rol C-529-2014, del 22 de marzo de 2017

El conflicto se inicia a partir del momento en que el Servicio de Salud Valdivia llama a una licitación pública denominada «Reposición Ascensores Dirección de Salud Valdivia» por resolución exenta número 3531 de 2011 que aprueba las bases administrativas, suscribiendo contrato con la demandada y aprobado el 30 de diciembre de 2011 bajo resolución exenta número 4501 de fecha 30 de diciembre de 2011, cuyo objeto principal es la instalación de dos ascensores marca Autür, provenientes de España. El costo de los ascensores es de $\$ 68.387 .872$, IVA incluido, y son pagados íntegramente como anticipo. No obstante, se deben instalar en un plazo de 270 días corridos. Como garantía, la demandante presentó boleta bancaria asumiendo la obligación de mantener vigente la boleta hasta la recepción de los ascensores, condición no cumplida al momento del vencimiento del plazo para la completa ejecución de los trabajos. 
Se alegan incumplimientos consistentes en el cambio unilateral de las especificaciones técnicas de los bienes ofertados que no fueron comunicadas ni autorizadas por su representada; omisión en la instalación de características incluidas en la oferta presentada por la demandada en el correspondiente proceso de licitación; la no renovación de la boleta bancaria de garantía por el pago vía anticipo en los términos y plazos indicados en la cláusula décima del contrato suscrito entre las partes; la no renovación oportuna de la garantía de fiel cumplimiento del contrato de acuerdo con lo indicado en la cláusula sexta del contrato; y el retardo imputable en la entrega e instalación de los bienes adquiridos por un total de 172 días.

En consecuencia, se demanda la resolución de contrato por incumplimiento y el pago de una indemnización de perjuicios por la suma de \$192.408.463 más intereses y reajustes, como indemnización por los gastos directos asumidos por la demandante, la indemnización moratoria y perjuicios morales desglosados en daño emergente por el pago anticipado del valor del contrato; precio pagado para poder dar término a los trabajos contratados realizado con recursos propios; servicios profesionales de un certificador acreditado por el Ministerio de Vivienda y Urbanismo; contratación de otro profesional durante la época en que se puso término anticipado al contrato; servicios prestados por un certificador por segunda vez; daños derivados del retardo en el cumplimiento de acuerdo con la cláusula octava del contrato suscrito. Finalmente, se señala que el retraso deriva en la aplicación de la multa a título de indemnización moratoria y daño moral por el honor, prestigio, confianza e imagen de su representada causados por el mal funcionamiento de los ascensores.

La demandada argumenta caso fortuito y fuerza mayor para justificar el incumplimiento, y señala que no le son imputables los eventuales daños sufridos por el motor.

En lo relevante, la réplica de la demandante funda su acción en que el derecho privado aplica en defecto de las normas de derecho público, las cuales a su vez son supletorias de la Ley 19.886. En consecuencia, al contrato se integran las bases administrativas y técnicas, y la oferta del contratista, entre otros, contando la administración con la atribución de poner término anticipado y unilateral al contrato.

El tribunal declara resuelto el contrato por incumplimiento y acoge parcialmente la demanda, concediendo solo indemnización por el daño emergente y señalando que el contrato administrativo celebrado por las partes fue un contrato administrativo. En el considerando noveno se cita al profesor Claudio Moraga Klenner en Contratación Administrativa (2007), quien señala que:

Cada parte deberá cumplir sus obligaciones en la forma contraída y deberá estarse a lo pactado, sin que le sea posible eximirse de dicho cumplimiento, sino en las circunstancias especialmente previstas en el mismo contrato o en la ley.

Además, en el mismo considerando se agrega una remisión a la sentencia de la Corte Suprema de Justicia, rol 6988-2012 de 2013, donde se define el contrato administrativo como «cualquier contrato en que una de las partes es la administración, sin 
importar mayormente si en él esta actúa en el ámbito de sus potestades exorbitantes o en un plano de igualdad con los particulares».

Por otra parte, se señala que el Servicio de Salud Valdivia ha actuado en el ámbito de sus "potestades exorbitantes» al poner término anticipado al contrato y sancionar con multa a la empresa demandada, revelando su poder sancionatorio reconocido en caso de infracción de deberes con carácter ex lege por los artículos 3 y 51 de la Ley 19.880 y la Ley de Compras Públicas. Además, se recomienda la revisión de Ferrada Bórquez (2007), específicamente del artículo «Las potestades y privilegios de la administración pública en el régimen administrativo chileno».

Finalmente, en lo relevante, en la fase o iter de contratación rige la normativa específica de la Ley 19.886 y su reglamento y, supletoriamente, las normas de derecho público. En su defecto, también rige el derecho común cuando establece que, en materia de contratación administrativa, la administración cuenta con la atribución de poner término anticipado y unilateral al contrato cuando se verifica un incumplimiento de obligaciones previstos en las bases o en el contrato.

\section{Sentencia del 6. ${ }^{\circ}$ Juzgado Civil de Santiago, rol C-32605-2015,} del 27 de febrero de 2017

La Inmobiliaria Cautín S.A presenta demanda en procedimiento sumario contra el fisco de Chile por término de contrato de arrendamiento por no pago de rentas, cobro de rentas adeudadas y restitución inmediata del inmueble objeto del contrato entre el demandante y el Ministerio del Interior y Seguridad Pública, quien con fundamento en la disponibilidad presupuestaria de la institución dio termino al contrato mediante oficio número 7809 sin respetar la prórroga tácita anual estipulada, incumpliendo diversas cláusulas del contrato y, en específico, la cláusula tercera, que señala:

Plazo de contrato. El presente contrato de arrendamiento tendrá una vigencia inicial desde el día 08 de marzo de 2014 hasta el 31 de diciembre de 2014, y transcurrido dicho plazo, el contrato se renovará anualmente en forma tácita y automática hasta el 31 de diciembre de 2015, y luego hasta el 31 de diciembre de 2016 y luego hasta el o7 de marzo de 2017. No obstante, tal vigencia estará supeditada anualmente a la disponibilidad presupuestaria del arrendatario. ${ }^{2}$

Esta cláusula es interpretada por la demandante como una revisión procedente en forma anual y no en forma intempestiva como lo interpreta la demandada.

El demandante solicita el término del contrato, la obligación de la demandada de pagar las rentas adeudadas más intereses penales, los gastos comunes adeudados más

2. El decreto exento del Ministerio del Interior y Seguridad Pública número 1.116 aprueba contrato de arrendamiento celebrado con fecha 10 de marzo de 2011 entre el Ministerio del Interior y Seguridad Pública e Inmobiliaria Cautín. El contrato original fue complementado mediante el decreto exento del Ministerio del Interior y Seguridad Pública número 3.467 de 2011 y modificado mediante el decreto exento del Ministerio del Interior y Seguridad Pública número 1408 de 2014. 
intereses, el pago de las rentas que se devenguen durante la sustanciación del juicio aumentadas en un 50\%, el pago de costas del juicio y la restitución inmediata del inmueble.

El fundamento jurídico de la pretensión se remite al Código Civil; en específico al artículo 1489 referido a la condición resolutoria tácita; al artículo 1947 referido a la obligación de restituir la cosa al fin del arriendo; y al artículo 1546 en razón de la buena fe.

El Fisco contesta la demanda argumentando que la naturaleza jurídica del acto celebrado es de un «contrato administrativo», que:

Como ha destacado la doctrina especializada, se caracteriza por la existencia de una serie de potestades exorbitantes de la administración, manifestación del plano de desigualdad jurídica en que se encuentran las partes, el formalismo de que se rodea su celebración y el objeto, de interés general, que este persigue, todas características que lo distinguen de su homónimo en sede civil o comercial y que determinan su sujeción a un estatuto especial de derecho público.

Por otra parte, agrega que la administración puede poner término unilateral del contrato, lo cual constituye una manifestación de las facultades exorbitantes antes indicadas avalado por los artículos 1 y 13 de la Ley 19.886.

El tribunal señala que la doctrina nacional ha sostenido que los elementos necesarios que configuran la existencia del contrato de suministro son que es un contrato administrativo que prosigue la provisión o abastecimiento de cosas muebles; que el suministro se hace a costa y riesgo del proveedor; y que el proveedor recibe una remuneración en dinero a cambio del suministro.

En consecuencia, establece que el contrato de arrendamiento en cuestión no puede determinarse como uno regulado en la Ley 19.886, ya que se trata de un contrato de arriendo sobre un bien inmueble.

Por esta razón es posible señalar que si bien el contrato no se rige por las normas de la Ley 19.886, sí actuó conforme a lo preceptuado en la Ley 16.436 , por lo que únicamente resta revisar si el fisco se adecuó a los términos del contrato. Las partes, al no existir una norma expresa de derecho público que regule el acto, deben atenerse al Código Civil y la Ley 18.101, que foja normas especiales sobre el arrendamiento de predios urbanos, precisando que al proveer al Estado de facultades que el ordenamiento jurídico no prevé en su actuación o en la observancia de sus obligaciones se estaría soslayando el artículo 19 número 2 de la Carta Fundamental, que contempla el principio de igualdad ante la ley, entrando en el terreno de lo arbitrario o de llevar a cabo decisiones antojadizas en vínculos jurídicos por los que resulte obligado en su actuar.

Para resolver revisa en su razonamiento el Código Civil como norma aplicable, en específico el artículo 1545 en materia de contratos, y los artículos 19, 1560 y 1564 en relación con la hermenéutica y a la cláusula tercera en conflicto, determinando que la facultad de terminar anticipadamente el contrato le estaba autorizada solo para efectos de condicionar la vigencia anual del contrato según se lee explícitamente en el contrato, estimando que el fisco vulneró la ley del mismo, por lo que se acoge parcialmente la acción principal declarando terminado el contrato y la condena al fisco a pagar las rentas 
devengadas y consumos básicos hasta la data de la restitución del inmueble; esto es al 6 de mayo de 2016 según lo razonado en lo considerativo y debidamente reajustadas, rechazando la condena al pago de rentas de arriendo con intereses.

Sentencia del $3 .^{\circ}$ Juzgado de Letras de Iquique, rol C-5439-2014, del 8 de febrero de 2017

El Fisco de Chile deduce demanda de cumplimiento forzado de contrato en juicio de hacienda y en subsidio la terminación de contrato con indemnización de perjuicios por los incumplimientos más intereses y reajustes, consecuencia del contrato de construcción denominado «Mejoramiento Ruta A-76o sector Nueva Victoria, comuna de Pozo Almonte, provincia del Tamarugal, región de Tarapacá». Finalmente, en caso de que las acciones interpuestas no sean acogidas, se interpone acción in rem verso por enriquecimiento sin causa fundada en que durante la ejecución del contrato se habrían verificado modificaciones al proyecto contratado con respecto a su materialidad, su rasante, diseño geográfico y forma de ejecución.

En la contestación de la demanda, el fisco de Chile controvierte la litis y establece que debe resolverse conforme a las normas, criterios y principios del derecho público, especialmente de los contratos de obra pública, basando en ello su argumentación.

En el considerando vigésimo octavo, el tribunal establece algunas consideraciones sobre el contrato administrativo mediante la reseña de una doctrina relevante. Nos referimos a Moraga Klenner (2007: 201, 202 y 204), quien indica que:

A la luz de lo establecido en el artículo 1545 del Código Civil, debe afirmarse que al igual que un contrato entre privados, también el contrato administrativo, celebrado o perfeccionado previo procedimiento de formación de la voluntad contractual, es una ley para los contratantes. Se agrega que «el contrato se rige por las normas legales y reglamentarias que lo tipifican o regulan, por las normas y cláusulas de las bases de licitación, por la oferta adjudicada y por las demás concernientes prescripciones técnicas, generales y particulares. Con el perfeccionamiento del contrato, ambas partes -administración pública y contratante particular- asumen la obligación de ejecutar de buena fe dicho contrato y cumplir las obligaciones que se imponen para cada una de ellas». En otras palabras, cada parte deberá cumplir sus obligaciones en la forma contraída y deberán estarse a lo pactado, sin que les sea posible eximirse de dicho cumplimiento, sino en las circunstancias especialmente previstas en el mismo contrato o en la ley.

En el mismo considerando se establece que:

La ejecución del contrato a riesgo y ventura del contratista es una regla que explica que los eventos que empeoren su situación no debieran constituirse en un obstáculo para dar cumplimiento a lo pactado, puesto que de aceptarse ello sin una causa justificada y reconocida por el marco jurídico que le rija, se facilita muy seguramente una probable suspensión del servicio o bien público ínsito en el contrato, con evidente perjuicio para el usuario o administrado en general. 
Por otra parte, en el considerando vigésimo noveno se agrega que:

Se debe consignar que la contratación administrativa se rige por principios que están recogidos por los instrumentos jurídicos que regulan la relación de particulares con la administración. La desigualdad en este tipo de contratos hace que la administración reciba un conjunto de poderes que la sitúan en un plano de superioridad respecto de su contratante, ya que los términos del contrato vienen expresados en las bases de licitación, donde se fijan las condiciones de la contratación. El contrato constituye el medio para que el servicio público logre satisfacer el interés público, por lo que debe ser flexible, de manera que si las circunstancias lo hacen necesario, la administración pueda adaptar sus condiciones a las nuevas necesidades, de manera que el contrato sea cumplido, (construyendo la obra) o bien poniendo término al mismo, facultad de modificación o ius variandi que se realiza sin consulta a la otra parte, pero sometida a condiciones establecidas por ley, y que permite modificar la convención cuando las circunstancias que lo han motivado cambian, haciendo la correspondiente revisión y adecuación de ésta a las circunstancias sobrevinientes. Al tratarse de un privilegio para la administración, debe ir acompañado de la correspondiente indemnización al contratante, o del alza de precio del contrato en su caso.

La doctrina señala que esta prerrogativa de la administración exige una cuidadosa y fundada apreciación de los antecedentes de hecho y de derecho que lo hacen necesario o conveniente, ya que en su virtud se alteran los términos del contrato, de modo de alcanzar la finalidad pública de una manera eficiente.

En el considerando trigésimo y en base al decreto supremo del Ministerio de Obras Públicas de Chile 75 del año 2004, en los artículos 102 y siguientes se señala que:

En el caso del contrato de construcción de obra pública, tanto en la modalidad a suma alzada como a serie de precios unitarios, la administración puede modificar las obras previstas; ordenar la ejecución de obras nuevas o extraordinarias; ordenar el empleo de materiales no considerados inicialmente; disminuir o aumentar las obras contratadas; paralizar la construcción de las obras.

El tribunal determina que la administración sí entregó los antecedentes necesarios y suficientes para que el contratista determinara en su oferta tanto los precios unitarios y cantidades asociadas a las partidas que permitieron terminar la obra y renunciar a las indemnizaciones legales y reglamentarias, rechazando la demanda de la empresa en todas sus partes.

Sentencia del 1. ${ }^{\circ}$ Juzgado de Letras de Iquique, rol C-2459-2014, del 21 de diciembre de 2016

En este caso, la sociedad comercial Building Service Ltda. interpone demanda de cumplimiento de contrato con indemnización de perjuicios contra la Dirección de Bienestar Social de la Fuerza Aérea. La demanda se basa en el contrato con que la empresa demandante se obligó a prestar servicios de conserjería, extracción de basura, man- 
tención de aseo y mantención de jardines en el inmueble fiscal. Argumenta que en la cláusula décima del referido contrato se estipula que la duración del mismo sería hasta el 31 de diciembre de 2012, pudiéndose renovar por el periodo siguiente de un año calendario, es decir, el día 31 de diciembre del año 2013 si ninguna de las partes manifestaba su intención de terminarlo. Para esto debía enviarse aviso por carta certificada con 30 días de anticipación, circunstancia en que el proveedor debía renovar la garantía equivalente al $10 \%$ del valor del contrato.

El contrato fue renovado tácitamente en virtud de la cláusula anteriormente reproducida y la aquiescencia de la parte demandada hasta que, sin mediar aviso, con 30 días de antelación la institución dio instrucciones a los trabajadores de la demandante para que dejaran de trabajar, impidiendo el ingreso normal a sus puestos de trabajo y terminando de forma unilateral, arbitraria e irregular por la demandada, provocando perjuicios pecuniarios y laborales al no poder configurar la causal del artículo 161 de Código del Trabajo. A partir de esto, las acciones se fundamentan en los artículos 1545, 1546, 1547 y 1556 del Código Civil.

El tribunal rechaza la demanda y señala que en los denominados contratos administrativos, si bien aplican las normas de derecho privado, lo hacen con distinta intensidad, rigiéndose fundamentalmente por las normas del derecho público, rector de los contratos en cuestión, permitiendo a la administración sujetar su actuación estrictamente dentro del marco de las bases generales y especiales del contrato en concreto, que constituyen la ley del mismo, y no pueden ser alteradas o modificadas salvo disposición legal, reglamentaria o contractual que lo admita.

El examen de la prueba le permite concluir al tribunal que no existe constancia o documento que acredite la autorización de una segunda renovación o prórroga, expresa o tácita, como tampoco disposición legal, reglamentaria o evento especial sobreviniente que justifique la prolongación del contrato administrativo, materia que no estaría tratada en las normas de contratación administrativa, cuya aplicación transgrede los principios de transparencia y publicidad del procedimiento administrativo contemplados en la Ley 18.575.

Sentencia del 1. ${ }^{\circ}$ Juzgado Civil de Los Ángeles, rol C-5884-2014, del 23 de noviembre de 2016

En este caso, la empresa Meganorte S.A demanda cumplimiento de contrato con indemnización de perjuicios contra la Municipalidad de Los Ángeles fundando su acción en que el contrato de configuración e instalación del sistema de televigilancia, pactado bajo la modalidad de contratación directa, no fue cumplido por la demandada, ya que no pagó por los períodos facturados correspondientes a los meses de agosto y septiembre de 2012 efectivamente trabajados, aplicando multas y descuentos por no tener en funcionamiento las cámaras, que no operaban por haber perdido su vida útil. Agrega que el objeto del contrato era la mantención y supervisión del sistema de televigilancia sin que el número de cámaras haya sido un factor para determinar el pago, salvo que el 
defecto se debiera a culpa de su mandante, siendo lo que en base al contrato correspondía, que la entidad edilicia costeara su reparación o reposición.

La municipalidad interpone excepción de contrato no cumplido, y el tribunal resuelve acoger parcialmente la demanda determinando el cumplimiento y el pago equivalente a los descuentos aplicados por concepto de multa, señalando que el contrato suscrito bajo modalidad de contratación directa se trata de un contrato administrativo, que en el considerando séptimo se define como:

Aquel celebrado entre un órgano de la administración del Estado y un particular u otro órgano público, cuyo objetivo es satisfacer de manera directa e inmediata un fin de interés público, a través de la aplicación del régimen normativo de derecho administrativo.

Dentro de sus características se cuenta la primacía de la administración por sobre la voluntad del particular; que son contratos solemnes, cuya regla general es el sometimiento a un régimen concursal para su adjudicación donde se busca la participación del particular en la concreción de asuntos públicos en virtud de sus méritos profesionales, otorgando justificación a su selección y a los montos que destine el Estado como pago al trabajo encomendado. En proceso se rige por el principio en el proceso selectivo y en la contratación.

En los contratos administrativos se manifiesta un predominio de la administración en la ejecución como el poder de control, modificación e interpretación unilateral del contrato, como manifestación de su papel protector de intereses públicos, admitiendo causales de terminación que no son propias de la contratación civil, como la caducidad y la revocación, que lo caracteriza como un régimen contractual público.

En atención a que no se acredita la facultad de la demandada para aplicar los descuentos, lo que a juicio del tribunal constituye una arbitrariedad en la ejecución del contrato por parte de la demandada, ya que si bien constituyen facultades propias de la administración, estas tienen límites. En el considerando undécimo se señala que:

La contratación pública de la administración, como se ha señalado, regularmente va asociada a la naturaleza de las prestaciones públicas en ella involucradas. De ahí entonces, que los contratos que celebre la administración puedan verse alterados por las necesidades a los cuales ellos van asociados. La mutabilidad del contrato ofrece una doble vertiente. De una parte, es la consecuencia del ius variandi que se reconoce a la administración; de otra, resulta de la admisión de una serie de teorías encaminadas a explicar, en beneficio del contratista, la adaptación del contrato a circunstancias sobrevinientes. Sin embargo, la mutabilidad del contrato, que se justifica en el interés público involucrado, debe compatibilizarse con el derecho del contratista de la administración a que sus derechos sean debidamente garantizados. Por ello, el proyecto garantiza patrimonialmente al contratante frente a la mutabilidad del contrato, sea a través del alza del precio, sea a través de la indemnización correspondiente. 
Argumenta que no hay igualdad entre la administración y su contratante, ya que el primero satisface un interés general y el segundo un interés particular, señalando que las resultas son de suma importancia para el Estado, razón por la que se contempla como facultad la mutabilidad, dirigir la ejecución del contrato, modificar e interpretar, sin perjuicio de las facultades de los tribunales de justicia, no invocando la demandada en el caso particular, la concurrencia de ninguna causal para modificar el contrato y aplicar multas, vulnerando los principios de la Ley 19.886.

Sentencia del $3 .^{\circ}$ Juzgado Civil de Antofagasta, rol C-2413-2013, del 16 de noviembre de 2016

En este litigio, el consorcio Comsa Pillasi demanda al Servicio de Salud Antofagasta por el incumplimiento de contrato emanado de la licitación pública «Construcción Hospital Carlos Cisternas de Calama», en razón del término unilateral del contrato y el cobro de la boleta de garantía por parte de la institución.

El tribunal rechaza la demanda y en el considerando cuarto establece que «hoy se acepta que la administración, aun actuando como poder público, es decir, dictando actos de autoridad, necesita de colaboradores, especialmente empresarios, que de común acuerdo con la administración realicen tareas para alcanzar el bien común».

Posteriormente, en el mismo considerando se agrega que «de esta manera, a la figura jurídica tradicional de los "actos administrativos", o actividad unilateral de la administración del Estado, se le ha sumado la concepción de los "contratos administrativos", o "actividad bilateral de la administración del Estado"».

También se cita al profesor Enrique Silva Cimma, quien señala que:

El ius variandi o poder de modificación del objeto del contrato comprende no solo el aspecto procesal de disponer unilateralmente la modificación de las reglas contractuales, sino que también el efecto sustantivo de exorbitar unilateralmente el fondo de la relación contractual en cuanto a variar las prestaciones asumidas por el contratista, resultado que marca una vertical diferencia con los contratos civiles, que, a la inversa, se rigen por la regla contraria sobre inalterabilidad de lo pactado por la sola voluntad de una de las partes, conocida con el aforismo "pacta sunt servanda».

Considera la relevancia del principio de juridicidad o legalidad, y del principio de la confianza legítima, ética y buena fe, establecidos como límites a los poderes unilaterales de la administración como consecuencia de la seguridad jurídica.

Sentencia del $1 .^{\circ}$ Juzgado de Letras de Talagante, rol C-640-2014, del 7 de noviembre de 2016

CGE Distribución interpone demanda de cumplimiento de contrato e indemnización de perjuicios, y en subsidio demanda de cobro de pesos con base en el contrato adjudicado por decreto alcaldicio denominado «Reposición de Luminarias Públicas de la Comuna de Talagante». La municipalidad cumple con su obligación de pago solo hasta 
la cuota 40 de 120 y deja de pagar las cuotas consecutivas, 60 de las cuales se encuentran vencidas e impagas.

El demandado opone las excepciones de nulidad del contrato, excepción de contrato no cumplido y prescripción de la acción de cobro de las obligaciones contractuales para finalmente deducir demanda reconvencional.

El tribunal acoge la demanda de cumplimiento forzado con indemnización de perjuicios, estableciendo en lo relevante y citando en el considerando décimo octavo a Moraga Klenner (2010: 324), quien señala que:

En la contratación administrativa existe una pacífica convivencia del derecho administrativo con el derecho privado, puesto que, en definitiva, todo contrato que celebra la administración es capaz de reflejar elementos de una y otra rama del derecho, sin que por ello varíe su esencia, sino solamente la intensidad de las distintas reglamentaciones que le son aplicables. Y, según la mayor o menor intensidad del régimen de derecho público, los diversos contratos que celebra la administración pueden ser más próximos al derecho administrativo o al derecho privado.

Adicionalmente, se cita a Bermúdez Soto (2011: 23) y se establece que:

El derecho administrativo se aplica siempre a la administración pública, salvo que actúe como sujeto sometido al derecho común. [...] Un problema que presentan estas zonas de fricción es el de la integración de las lagunas; es decir, si procede llenar tales vacíos en el derecho administrativo con las normas del derecho general. Resulta difícil dar aquí una respuesta a este problema, no obstante, un criterio de seguridad jurídica, sumada a la referida precariedad normativa de nuestro derecho administrativo, deberían llevarnos a optar por la afirmativa.

Finalmente, con respecto a la excepción de nulidad contractual, señala que ella ha de regirse por el título XX del libro IV del Código Civil en lo relacionado con el repertorio de causales, legitimación, efectos, saneamiento, prescripción y principios generales aplicables.

\section{Sentencia del $1 .^{\circ}$ Juzgado Civil de Puerto Montt, rol C-940-2014,} del 6 de octubre de 2016

José Martínez Cortez interpuso demanda de cobro de dinero e indemnización de perjuicios contra la Municipalidad de Puerto Montt, la cual se deriva de la licitación pública para construir el jardín infantil y sala cuna Chinquihue. El demandante se funda en el retardo en la ejecución de las obras, la entrega unilateral y administrativa del terreno en que se dispuso la corrección unilateral del diseño original, y en el incumplimiento en pagos acordados por contrato con base en el artículo 1545 del Código Civil.

El tribunal rechaza la demanda y en el considerando vigésimo noveno cita a Bermúdez Soto (2010: 141-150) cuando afirma que: 
No se puede olvidar que en el contrato que nos convoca, una de las partes es un órgano de la administración del Estado y que su objeto es la satisfacción de una necesidad pública, a lo que sigue que la convención en estudio es un contrato administrativo, tipos de contratos que se caracterizan por contener dentro de su regulación cláusulas de carácter exorbitante es decir, determinadas cláusulas que colocan a la administración pública en una situación de privilegio respecto de la otra parte, siendo manifestaciones de dichas cláusulas exorbitantes durante la ejecución de la obra, las potestades sancionatorias y de incentivo que, se traducen en que ante el incumplimiento del contrato o el retraso en la ejecución del mismo, al administración podrá imponer las sanciones que correspondan, las que en general serán multas que se traducirán en descuentos de los estados de pago.

\section{Sentencia del $1 .^{\circ}$ Juzgado Civil de Temuco, rol C-6145-2014, del 15 de marzo de 2016}

En esta hipótesis, la empresa demanda cumplimiento de contrato con indemnización de perjuicios con base en la licitación pública adjudicada denominada «Provisión e Instalación de Tachas Led Solares», solicitando la devolución de la garantía de fiel cumplimiento y perjuicios anexos con fundamento principal en los artículos 1545, 1489, 1551,1553, 1556 y 1557 del Código Civil.

El tribunal resuelve que habiéndose acreditado por el actor el cumplimiento de las obligaciones asumidas en el contrato y reconocido el no pago del precio por la demandada sin demostrar que ese incumplimiento sea injustificado, se acoge íntegramente la demanda. Para referirse a los contratos administrativos se cita a Bermúdez Soto (2014: 196), quien señala que:

Tiene su origen en Francia, como desarrollo de la jurisprudencia del Consejo de Estado, y con la finalidad de sustraer este tipo de acto del conocimiento de los tribunales ordinarios, el concepto fue recogido también por España y como consecuencia paso a formar parte de nuestra doctrina y jurisprudencia. Nuestra doctrina lo ha definido como: «un acuerdo de voluntades entre organismos de la administración del Estado que actúa dentro de su giro propio y en ejercicio de sus competencias específicas, y un particular u otros organismo público que actúa como particular y no dentro de sus competencias específicas, que tiene por objeto la satisfacción de necesidades públicas, produciendo entre ellas derechos y obligaciones».

Con respecto a la doctrina minoritaria, la sentencia determina que los contratos administrativos se ajustan mejor a la idea de una «resolución parcialmente consensuada con el particular», presentándose la voluntad del contratista al presentar su propuesta, siendo su voluntad participar en el proceso y no convenir.

Son mencionados los conceptos de ius variandi, interpretación y equilibrio financiero, presentando como elementos típicos del contrato las partes del contrato son la administración pública y el contratista; que el objeto es la satisfacción de una necesidad pública con carácter real y lícito; que las formalidades incluyen un proceso licitatorio, 
la dictación de decretos o resoluciones que adjudiquen, entre otros; que existen cláusulas exorbitantes, que son aquellas que hacen que la administración aparezca en una situación de superioridad jurídica respecto del contratante y que tiene como característica que estos poderes «exorbitantes» tienen su origen en la ley y no del contrato, se justifican en el interés general al que sirven los contratos, a través de estas prerrogativas la administración no se sirva a sí misma, sino que asegura la realización de obras contratadas o la prestación del servicio pactado. Además, con respecto a la legislación aplicable se rigen por normas y principios propios del derecho administrativo. Por otra parte, entre los principios observados se cuentan la desigualdad, de la cual derivan consecuencias, como que la administración no puede alterar la oferta; la administración debe aceptar o rechazar la oferta en bloque; el contratista está obligado a constituir garantías a favor de la administración; la administración puede ejercer su potestad disciplinaria sobre el contratante privado, aplicando sanciones en caso de incumplimiento y puede modificar unilateralmente los términos del contrato. Finalmente, con respecto al principio de legalidad y ley del contrato, esta los obliga a considerar la normativa del ordenamiento jurídico que pasa a formar parte del contrato.

Otros principios consideran la mutabilidad del contrato administrativo (ius variandi); equivalencia prestacional, que contempla como contrapartida a las cláusulas exorbitantes, el derecho al equilibrio económico financiero del contrato como garantía a la modificación de condiciones pactadas originalmente; principio de colaboración, que caracteriza al contratista como un colaborador, por lo que es posible flexibilizar los tiempos de ejecución o acordar nuevas obras; y principio de ejecución del contrato de buena fe.

Finalmente, con respecto a los privilegios de la administración pública, se consideran la autotutela decisoria y ejecutiva, cuya característica es la facultad de terminar anticipadamente el contrato o suspender la ejecución por falta de fondos o por necesidades de la administración; interpretación unilateral de las cláusulas de los contratos; modificación y término unilateral del contrato; dirección y control de la ejecución del contrato, que supone la posibilidad de impartir órdenes al contratista, traducido en la presencia de un inspector técnico en la obra y reuniones periódicas; potestades sancionatorias y de incentivo, traducidas en suspensión automática del registro general de contratistas, aplicación de multas por incumplimiento de cláusulas contractuales, término anticipado, entre otras.

Sentencia del $1 .^{\circ}$ Juzgado Civil de Iquique, rol C-4114-2013, del 2 de marzo de 2016

La empresa Espacio y Jardín Ltda. demanda resolución de contrato a la Municipalidad de Iquique con base en la prestación del «Servicio de provisión, instalación y mantención de macetas ornamentales de la comuna de Iquique», por contravenir estipulaciones establecidas en la propuesta técnica, cursar multas e incumplir los términos mediante los cuales deben efectuarse las inspecciones. 
Se rechaza la demanda y en el considerando octavo se señala sobre el contrato administrativo que:

Tiene diversos elementos especiales que lo caracterizan y lo diferencian del contrato de derecho privado, a saber: a) una de las partes es un ente de la administración pública; b) deben existir en dicho contrato cláusulas exorbitantes; c) siempre debe ser reconocible el interés público; d) la administración pública siempre contrata dentro de lo estrictamente administrativo; e) se encuentra regido por las normas y principios del derecho público.

Por otra parte, en el mismo considerando y en relación con las cláusulas exorbitantes se puntualiza que:

Derivan en una serie de consecuencias jurídicas, tales como que la administración tiene facultades de dirección y control sobre la forma y modo de cumplir el contrato; puede modificar los términos del contrato unilateralmente; incluso, puede dar por terminado el contrato unilateralmente, sin necesidad de recurrir al órgano judicial.

\section{Jurisprudencia de los tribunales superiores de justicia}

Sentencia de la Corte de Apelaciones de Iquique, conociendo recurso de apelación, rol 570-2016, caratulada «Espacio y Jardín Ltda. con Ilustre Municipalidad de Iquique», de 30 de diciembre de 2016

Sobre los contratos administrativos, la Corte de Apelaciones de Iquique menciona en el considerando quinto que:

Así las cosas, sin perjuicio de que la administración está provista de facultades exorbitantes, estas deben ejercerse de acuerdo con el principio de juridicidad, proscribiendo su ejercicio de manera abusiva y arbitraria, debiendo ajustarse, entre otras, a las normas de los artículos 6 y 7 de la Constitución Política; a las normas pertinentes de la Ley Orgánica Constitucional de Bases Generales de la administración del Estado; a la Ley Orgánica Constitucional de Municipalidades; a la propia Ley 19.886; a la Ley 19.880 sobre Procedimientos Administrativos; a las bases administrativas y sus especificaciones técnicas; y a las normas de derecho privado sobre contratación bilateral.

Sentencia de la Corte Suprema de Justicia, conociendo recurso de casación en el fondo, rol 11580-2015, caratulada «Arauco S.A. con Municipalidad de Lo Barnechea», 28 de enero de 2016

En el considerando tercero, la Corte Suprema establece que:

El contrato administrativo es una ley para los contratantes, no siendo jurídicamente posible dejarlo sin efecto o no cumplirlo por un motivo no contemplado en este. En efecto, todo contrato administrativo se rige por sus cláusulas, por las normas legales 
y reglamentarias que lo regulan, por las bases de licitación, por la oferta adjudicada y por las demás prescripciones técnicas, por lo que no es posible decidir en contra de la ley del contrato, pues se transgrede el principio de la autonomía de la voluntad.

Sentencia de la Corte Suprema de Justicia, conociendo recurso de casación en el fondo, rol 1126-2015, caratulada «Sociedad de Proyectos y Servicios de Ingeniería Limitada con Gobierno Regional de Tarapacá», 24 de agosto de 2016

En este caso, en el considerando primero la Corte Suprema indica que:

En nuestro ordenamiento jurídico el estatuto general de los contratos administrativos se encuentra en diversas leyes atinentes al sector público y no, como erróneamente sugiere de forma tácita la sentencia, en el Código Civil ni en los principios o criterios hermenéuticos del derecho privado, salvo de forma residualmente supletoria.

Con respecto a las facultades exorbitantes en el considerando noveno se plantea que:

El otorgamiento a la administración de ciertas prerrogativas especiales denominadas exorbitantes del derecho común, entre las que se incluye la de poner término anticipado a un contrato administrativo cuando concurre una justificación de interés público o general que le sirve de fundamento.

Sentencia de la Corte Suprema de Justicia, conociendo recurso de casación en el fondo, rol 1059-2014, caratulada «Sociedad de Inversión Bigmarketing con Municipalidad de Concepción», de 25 de agosto de 2014

En relación con la nulidad de la terminación anticipada, la Corte Suprema resuelve en el considerando quinto que:

No es posible declarar la nulidad de derecho público del acto de terminación de un contrato administrativo porque tanto el ordenamiento constitucional como el legal han reconocido y fundamentado la atribución entregada a la administración de ciertas prerrogativas especiales, entre ellas, la de poner término anticipado a un contrato administrativo cuando concurre una justificación del interés público o general que le sirve de sustento y en caso de verificarse un hecho de incumplimiento de obligaciones previsto en las bases administrativas o en el contrato.

\section{Dictámenes de la Contraloría General de la República}

\section{Dictamen 22.640/2009}

Referido a la indemnización por modificación de programa de trabajo en contrato de obra sobre «Construcción Segunda Pista y Rehabilitación de la Pista Actual Aeropuerto 
Arturo Merino Benítez» y base de cálculo, establece sobre la finalidad de los contratos administrativos y sus características que:

Por tratarse de un contrato administrativo cuya finalidad directa e inmediata es propender al bien público, la administración posee ciertas potestades exorbitantes, que difieren de las del derecho común, tales como la facultad de elaborar las bases de licitación, de dirigir e inspeccionar el cumplimiento del contrato y, en ciertos casos, de modificar el mismo, para su mejor ejecución.

Adicionalmente, se menciona que:

Existen ciertas situaciones en que la autoridad administrativa requiere que se modifique el plan de trabajo y que de ello derive una ampliación del plazo para llevar a término la obra, lo que bajo determinados supuestos da lugar a la indemnización de los perjuicios que al efecto puedan ocasionarse al contratista.

\section{Dictamen 91.219/2014}

Referido al término anticipado del contrato entre la Corporación Idea País e INJUV, se señala que:

El servicio se encontraba habilitado para ejecutar la cláusula aludida debido a la facultad exorbitante con que cuenta la administración, que nace de la ley, y es la manifestación de uno de los principios orientadores de la contratación, específicamente el de «desigualdad» en las relaciones contractuales con los particulares.

\section{Dictamen 34.523/2013}

Referido a la legalidad de aplicar una multa considerada como abusiva se señala que:

Los dictámenes 30.642 de 1989, 5.287 y 6.010, ambos de 1992, entre otros, han reconocido que las estipulaciones contractuales que contienen multas asociadas al incumplimiento de las obligaciones convencionales tienen el carácter de cláusula penal, la que se encuentra definida por el Código Civil en su artículo 1.535 como aquella en que una persona, para asegurar el cumplimiento de una obligación, se sujeta a una pena, que consiste en dar o hacer algo en caso de no ejecutar o retardar la obligación principal, disposición que se aplica supletoriamente a las contrataciones regidas por la Ley 19.886 según lo prevé su artículo 1 antes aludido.

\section{Dictamen 46.532/200o}

Como consecuencia a una solicitud de pronunciamiento con respecto a la expresión «contratos administrativos» se determinó que:

Los dictámenes 29.401 de 1984 y 12.251 de 1993, y como también se infiere de lo 
dictaminado en el oficio número 14.540 del presente año, la expresión contrato administrativo se entiende con un alcance amplio, en el sentido de que abarca los diversos tipos de contratos que celebren los entes de la administración, tanto en el ámbito de sus potestades exorbitantes como en el de su actuación en un plano de igualdad con los particulares.

\section{Conclusión}

Resulta relevante cómo la jurisdicción civil se ha hecho cargo de una materia con la especificidad de la contratación administrativa, en el entendido de que el Tribunal de Contratación Pública tiene competencia solo desde la aprobación de las bases de la respectiva licitación hasta su adjudicación. Es por esta circunstancia que la aplicación de las normas civiles toma mayor fuerza, supliendo en forma reiterada y consistente en aquellos casos en que no es posible aplicar la Ley 19.886 y su reglamento, o las normas del derecho público.

Son reiteradas las sentencias que resuelven acciones de cumplimiento o resolución de contrato con indemnización de perjuicios y cobro de prestaciones, presentados tanto por los proveedores del Estado como por el fisco, resolviendo generalmente con énfasis en los siguientes aspectos.

- La figura del contrato como acuerdo de voluntades que genera derechos y obligaciones entre quienes lo celebran, constituye una institución que trasciende la división del derecho público o privado.

- Siendo las normas del derecho público insuficientes para dar vida a un contrato por el imperativo de poder únicamente aquello que autoriza expresamente la ley, es que es necesario recurrir preferentemente al derecho civil para interpretar o definir palabras como «mora», «incumplimiento», «terminación», «pago», «indemnización» y en general las que conllevan la vida de un contrato, resultando del todo aplicable el artículo 1545 del Código Civil. El derecho público no es autosuficiente a diferencia del derecho civil, cuya aptitud es:

- Aplicar válidamente sus categorías y principios generales para deducir reglas no escritas aplicables a los hechos que no se encuentran regulados ni por el Código Civil ni por una ley sectorial (Sentencia del $3 .^{\circ}$ Juzgado Civil de Calama, rol C-115-2016, 2017: considerando vigésimo).

- Todo contrato que celebra la administración es capaz de reflejar elementos de una y otra rama del derecho sin que por ello varíe su esencia, sino solamente la intensidad de las distintas reglamentaciones que le son aplicables. Y según la mayor o menor intensidad del régimen de derecho público, los diversos contratos que celebra la administración pueden ser más próximos al derecho administrativo o al derecho privado. 
- A la luz de lo establecido en el artículo 1545 del Código Civil, debe afirmarse que al igual que un contrato entre privados también el contrato administrativo, celebrado o perfeccionado previo procedimiento de formación de la voluntad contractual, es una ley para los contratantes.

- El concepto de contrato administrativo puede caracterizarse como:

- Aquel celebrado por un órgano de la administración del Estado y un particular u otro organismo público, cuyo objeto es satisfacer de manera directa e inmediata un fin de interés público, a través de la aplicación de un régimen normativo de derecho administrativo (Sentencia del 2. ${ }^{\circ}$ Juzgado Civil de Viña del Mar, rol C-186-2014, 2017: considerando vigésimo).

- El acto previo al contrato es, por tanto, una facultad discrecional de la administración a través de un acto de autoridad y, en ejercicio de su potestad administrativa, decide transferir a particulares la satisfacción de una necesidad colectiva. El contrato tiene una naturaleza contractual solo en cuanto crea derechos, ya que constituye una declaración bilateral productora de efectos jurídicos entre dos personas, una de las cuales es un órgano de la administración del Estado que actúa en ejercicio de la función administrativa.

- El contrato administrativo tiene diversos elementos especiales que lo caracterizan y lo diferencian del contrato de derecho privado: una de las partes es un ente de la administración pública; deben existir en dicho contrato cláusulas exorbitantes; siempre debe ser reconocible el interés público; la administración pública siempre contrata dentro de lo estrictamente administrativo; y se rige por las normas y principios del derecho público.

- El contrato administrativo es una ley para los contratantes. No es jurídicamente posible dejarlo sin efecto o no cumplirlo por un motivo no contemplado en este. En efecto, todo contrato administrativo se rige por sus cláusulas, por las normas legales y reglamentarias que lo regulan, por las bases de licitación, por la oferta adjudicada y por las demás prescripciones técnicas, por lo que no es posible decidir en contra de la ley del contrato, ya que se transgrede el principio de la autonomía de la voluntad. Cada parte deberá cumplir sus obligaciones en la forma contraída y deberá estarse a lo pactado, sin que le sea posible eximirse de dicho cumplimiento, sino en las circunstancias especialmente previstas en el mismo contrato o en la ley.

- Es posible aplicar las normas del derecho privado en defecto de las normas del derecho público, las cuales aplican supletoriamente a la Ley 19.886 y su reglamento.

- Sobre las partes del contrato prima la desigualdad toda vez que el régimen jurídico no puede significar un riesgo o peligro para el buen y adecuado funcionamiento del servicio público, configurando un proceso dinámico, adaptable 
a las circunstancias y situaciones producidas en el desarrollo del contrato. El contrato constituye el medio para que el servicio público logre satisfacer el interés público, por lo que debe ser flexible, de manera que si las circunstancias lo hacen necesario, la administración pueda adaptar sus condiciones a las nuevas necesidades, de manera que el contrato sea cumplido, (construyendo la obra) o bien poniendo término al mismo, facultad de modificación o ius variandi que se realiza sin consulta a la otra parte, pero sometida a condiciones establecidas por ley, y que permite modificar la convención cuando las circunstancias que lo han motivado cambian, haciendo la correspondiente revisión y adecuación de esta a las circunstancias sobrevinientes. Al tratarse de un privilegio para la administración, debe ir acompañado de la correspondiente indemnización al contratante o del alza de precio del contrato en su caso.

- Se contempla como contrapartida a las cláusulas exorbitantes el derecho al equilibrio económico financiero del contrato como garantía a la modificación de condiciones pactadas originalmente; principio de colaboración que caracteriza al contratista como un colaborador, por lo que es posible flexibilizar los tiempos de ejecución o acordar nuevas obras; y principio de ejecución del contrato de buena fe.

- Se manifiesta un predominio de la administración en la ejecución como el poder de control, modificación e interpretación unilateral del contrato, como manifestación de su papel protector de intereses públicos, admitiendo causales de terminación que no son propias de la contratación civil como la caducidad y la revocación, que lo caracteriza como un régimen contractual público.

- En materia de principios rectores es posible consignar como principios generales que rigen la contratación el respeto a las bases administrativas, la sujeción a lo pactado, la buena fe y la equivalencia de las obligaciones en favor de no existir enriquecimiento sin causa. Igualmente, la contratación administrativa se rige por el principio de legalidad y ley del contrato, el cual supone, por una parte, que la administración debe actuar (contratar) previa habilitación y sin contradicción con el ordenamiento jurídico; y por otra, que las partes no solo están obligadas por el tenor del contrato, sino también por la normativa que lo regula, la cual se entiende incorporada al contrato; es decir, los órganos del Estado deben someter sus actuaciones a la Constitución y a las leyes, debiendo actuar dentro de su competencia y en la forma prescrita por la ley y no están liberados de sujetarse a los principios y normas que rigen en materia civil. Resulta particularmente relevante el principio de ejecución de buena fe del contrato, el cual se traduce en que para ambos contratantes surge la obligación de lograr la realización de la finalidad del contrato, es decir, satisfacer el interés general, aportando cada uno de ellos los máximos esfuerzos y diligencias en su ejecución. Así, pesa sobre todo contratante el deber de actuar de buena fe, que le impone el artículo 1546 
del Código Civil, el que debe extender incluso a aquellos que las partes pudieran convenir consensualmente.

- Otros principios observados son la desigualdad, de la cual derivan consecuencias como que la administración no puede alterar la oferta; que la administración debe aceptar o rechazar la oferta en bloque; que el contratista está obligado a constituir garantías a favor de la administración; que la administración puede ejercer su potestad disciplinaria sobre el contratante privado, aplicando sanciones en caso de incumplimiento y puede modificar unilateralmente los términos del contrato.

- El Estado contrata para satisfacer una necesidad o interés público consagrándose prerrogativas y potestades exorbitantes para la administración, como la facultad de poner término anticipado del contrato por incumplimiento de las obligaciones del contratante. En materia de contratación administrativa, la administración cuenta con la atribución de poner término anticipado y unilateral al contrato cuando se verifica un incumplimiento de obligaciones previstos en las bases o en el contrato. En suma, un «contrato administrativo», que:

- Como ha destacado la doctrina especializada, se caracteriza por la existencia de una serie de potestades exorbitantes de la administración, manifestación del plano de desigualdad jurídica en que se encuentran las partes, el formalismo de que se rodea su celebración y el objeto, de interés general, que este persigue, todas características que lo distinguen de su homónimo en sede civil o comercial y que determinan su sujeción a un estatuto especial de derecho público» (Sentencia del $6^{\circ}$ Juzgado Civil de Santiago, rol C-32605-2015, 2017: Vistos).

- Agrega que la administración puede poner término unilateral del contrato, lo cual constituye una manifestación de las facultades exorbitantes.

- La mutabillidad del contrato, que se justifica en el interés público involucrado, debe compatibilizarse con el derecho del contratista de la administración a que sus derechos sean debidamente garantizados. Por ello, el proyecto garantiza patrimonialmente al contratante frente a la mutabilidad del contrato, sea a través del alza del precio, sea a través de la indemnización correspondiente.

- El ius variandi o poder de modificación del objeto del contrato comprende no solo el aspecto procesal de disponer unilateralmente la modificación de las reglas contractuales, sino también el efecto sustantivo de exorbitar unilateralmente el fondo de la relación contractual en cuanto a variar las prestaciones asumidas por el contratista, resultado que marca una vertical diferencia con los contratos civiles, que, a la inversa, se rigen por la regla contraria sobre inalterabilidad de lo pactado por la sola voluntad de una de las partes, conocida con el aforismo «pacta sunt servanda». 
- Con respecto a la resolución de contrato con indemnización de perjuicios, en aquellos casos en que se trata de una problemática de interpretación y ejecución del contrato, supone la posibilidad de aplicar el procedimiento ordinario.

- Los servicios públicos no pueden aprovecharse de sus propios errores en perjuicio de terceros, ya que se produciría un enriquecimiento sin causa para la entidad pública.

- La naturaleza de acto administrativo que adjudica un servicio en favor de un particular es compleja, ya que obliga al acto órgano del Estado a suscribir un contrato con un civil, constituyendo la unión entre un acto administrativo unilateral de la administración, que a la vez genera obligaciones recíprocas entre los contratantes.

- Sin perjuicio de la calidad de contrato administrativo del acuerdo, no existe inconveniente para la revisión del incumplimiento contractual en sede civil, aunque ya se hubiera resuelto en sede administrativa, señalando que la doctrina como la jurisprudencia se encuentran contestes en que una resolución administrativa no es obstáculo para que la parte afectada entable acciones para revisar la legalidad de los actos de la administración y demande indemnización de perjuicios.

- Se establece que la ejecución del contrato a riesgo y ventura del contratista es una regla que explica que los eventos que empeoren su situación no debieran constituirse en un obstáculo para dar cumplimiento a lo pactado, ya que de aceptarse sin una causa justificada y reconocida por el marco jurídico que le rija se facilita muy seguramente una probable suspensión del servicio o bien público ínsito en el contrato, con evidente perjuicio para el usuario o administrado en general.

- Se exige una cuidadosa y fundada apreciación de los antecedentes de hecho y de derecho que lo hacen necesario o conveniente, ya que en su virtud se alteran los términos del contrato de modo de alcanzar la finalidad pública de una manera eficiente.

- El derecho administrativo se aplica siempre a la administración pública, salvo que actúe como sujeto sometido al derecho común. Un problema que presentan estas zonas de fricción es el de la integración de las lagunas, es decir, si procede llenar esos vacíos en el derecho administrativo con las normas del derecho general. Resulta difícil dar aquí una respuesta a este problema, no obstante, un criterio de seguridad jurídica sumada a la referida precariedad normativa de nuestro derecho administrativo debería llevarnos a optar por la afirmativa.

- La doctrina minoritaria determina que los contratos administrativos se ajustan mejor a la idea de una «resolución parcialmente consensuada con el particular», presentándose la voluntad del contratista al presentar su propuesta, siendo su voluntad participar en el proceso y no convenir. 
En suma, la aplicación de las normas civiles en los contratos administrativos resulta necesaria en aspectos propios de la terminación del contrato con el objeto de equilibrar a las partes y limitar al Estado en su actuar, el que se encuentra revestido de facultades exorbitantes para cumplir el fin público propio de su naturaleza, concretado al transferir a particulares la satisfacción de una necesidad, quien se caracteriza como un «colaborador de la administración». Dichas clausulas exorbitantes se presentan como un elemento de relevancia entre las características de los contratos administrativos, sin embargo, no tienen carácter absoluto, ya que los tribunales han acogido la indemnización de perjuicios en los casos en que resultan abusivas, resultando relevante el concepto de ius variandi, no pudiendo los servicios públicos incumplir sus obligaciones excusándose en la existencia de facultades exorbitantes y la desigualdad de las partes.

Dentro de la jurisprudencia reseñada se ha determinado que el contrato administrativo trasciende la división público-privado, sin embargo, parece más certero afirmar que las normas son complementarias, ya que existen ámbitos de la contratación administrativa que no es posible cubrir por las normas de la Ley 19.886, su reglamento o el derecho público, por lo que resulta necesario y esencial recurrir a las normas del derecho civil. Así, dependiendo de la materia y de la etapa en que se encuentre la contratación, dependerá la proximidad al derecho administrativo o al derecho privado, sin que por esto la interpretación o integración de lagunas deje de ser cohesionada entre los diversos tipos de derecho implicados en el orden de prelación.

Existe claridad en la aplicación principal de los artículos 1545 y siguientes del Código Civil y, en consecuencia, es relevante la aplicación de los principios propios de la contratación, como la estricta sujeción a las bases y aquellos característicos del derecho civil, como la buena fe y el rechazo al enriquecimiento sin causa. Con respecto a los principios del derecho público, es de suma importancia la aplicación del principio de legalidad en cuanto los órganos del Estado deben someter sus actuaciones a la Constitución y a las leyes, debiendo actuar dentro de su competencia y en la forma prescrita por la ley, y no están liberados de sujetarse a los principios y normas que rigen en materia civil.

Sin perjuicio de lo anterior, es necesario que por parte de los tribunales se lleve a cabo una revisión exhaustiva del contrato sujeto a su conocimiento para determinar si es posible resolver el conflicto mediante la aplicación de las bases administrativas, de los principios del derecho público o a través de las normas de cumplimiento o terminación contenidas en el Código Civil. Sin embargo, se ha observado que es posible complementar dichas normas, no siendo excluyente de la resolución en sede civil la aplicación de principios contenidos en legislaciones de carácter especial o público, por lo que el orden de prelación no obsta a la aplicación complementaria de las normas, las cuales atendido su carácter presentarán un resultado óptimo si no se interpretan en forma aislada, sino que conjuntamente con base en el interés público y bien común perseguido.

Parece relevante señalar que si bien han sido revisadas sentencias que aplican los principios de la contratación administrativa para resolver, no es una constante en 
las resoluciones judiciales, existiendo tribunales que intuitivamente resuelven aplicando únicamente el derecho civil sin considerar aspectos particulares del derecho administrativo. ${ }^{3}$

Finalmente, es importante concluir que es necesario no perder de vista el hecho de que si bien el Estado tutela un derecho colectivo y sus prerrogativas especiales son necesarias para propender al bien común y el correcto funcionamiento de los servicios, no se puede desproteger a la parte contratante, que si bien se encuentra en desventaja en muchos aspectos, no puede ser parte de un trato abusivo para lo cual en su favor operan de mejor forma las normas del derecho civil para el cumplimiento de las normas del contrato. Ahora bien, corresponde la revisión casuística del contrato para determinar si la contratación administrativa se acerca a determinadas normas en perjuicio de otras o si, por otro lado, procede su aplicación complementaria.

\section{Referencias}

Bermúdez Soto, Jorge (2010). Derecho administrativo general. 1. ${ }^{\mathrm{a}}$ ed. Santiago: Abeledo Perrot.

-. (2011). Derecho administrativo general. 2. ${ }^{\mathrm{a}}$ ed. Santiago: Abeledo Perrot.

-. (2014). Derecho administrativo general. $3 .^{\text {a }}$ ed. Santiago: Thomson Reuters.

Carvajal, Patricio (2017). "Plus est in re quam in existimatione'. La terminación anticipada del contrato de concesión municipal por declaración administrativa unilateral. Aspectos de derecho privado y de derecho público». Revista de Derecho de la Pontificia Universidad Católica de Valparaíso, 46: 105-131. DOI: 10.4067/ So718-68512016000100003.

Concha MACHUCA, Ricardo (2013). «La fuente normativa de la fuerza obligatoria del contrato de la administración (artículo 1545 del Código Civil)». Revista Ius et Praxis, 19 (2): 467-476. DOI: 10.4067/So718-00122013000200016.

FERRADA BóRqueZ, Juan Carlos (2007). «Las potestades y privilegios de la administración Pública en el régimen administrativo chileno». Revista de Derecho de la Universidad Austral de Chile, 20 (2): 69-94. DOI: 10.4067/So718-09502007000200004.

Moraga Klenner, Claudio (2007). Contratación Administrativa. Santiago: Jurídica de Chile.

-. (2010). «La actividad formal de la administración del Estado». En Rolando Pantoja Bauzá (coordinador), Tratado de Derecho Administrativo. Tomo VII. Santiago: Legal Publishing.

Oelckers Camus, Osvaldo (1979). «En torno al concepto de contrato administrativo». Revista de Derecho de la Pontificia Universidad Católica de Valparaíso, 3: 135-16o. Disponible en https://bit.ly/32k3Ppa.

3. Como referencia, véase la sentencia del Juzgado de Letras de Pozo Almonte, rol C-58-2017, 2018, y la sentencia del 12. ${ }^{\circ}$ Juzgado Civil de Santiago, rol C-3608-2014, 2018. 
Vergara Blanco, Alejandro (2014). «La summa divisio iuris público-privado y la integración normativa en materias administrativas y civiles». Revista de Derecho Privado de la Universidad Externado de Colombia, 26: 43-69. Disponible en https://bit. ly/3oqHGUn.

\section{Sobre la autora}

Carolina Alejandra Pincheira Sepúlveda es abogada y licenciada en Ciencias Jurídicas y Sociales por la Universidad de Chile y magíster en Derecho, mención Derecho Regulatorio, de la Pontificia Universidad Católica de Chile. Se desempeña actualmente como abogada en la Contraloría Universitaria de la Universidad de Santiago de Chile. Su correo electrónico es carolinapincheira.s@gmail.com. (D) https://orcid. org/oooo-0002-4219-3379. 
